\title{
ENHANCEMENT OF STUDENTS COOPERATION ATTITUDE THROUGH TRADITIONAL GAME OF LOMPAT TALI
}

\author{
Iip Istirahayu \\ STKIP Singkawang, Singkawang, Indonesia \\ E-mail: iipistirahayu19@gmail.com
}

\begin{abstract}
Character development in students is very important to be a better individual and understand the values that apply. Character development is done by instilling basic ethical values such as one of which is cooperation. The purpose of this research is to find out and analyze the increase in the value of cooperation of elementary school students in the city of Singkawang through the application of the traditional Lompat Tali game, as a form of preserving the nation's culture and building the nation's cultural character. The method used in this research is quantitative research. The study population was all elementary school students in Singkawang. Samples were selected using a purposive sampling technique as many as 50 groups. The type of data used in this survey research is quantitative data obtained from interviews, observations, and attitude scales. Analysis of the data in this study used the N-gain test to see an increase in student cooperation attitude. The results of the study based on the $\mathrm{N}$-gain calculation show that the increase in the cooperative attitude of elementary school students is 0.38 , which means that students of the traditional game of Lompat Tali can increase the cooperative attitude of elementary school students.
\end{abstract}

Keywords: Traditional game; Lompat Tali; Cooperation; Primary School

\section{INTRODUCTION}

Cooperation is a social characteristic that cannot be separated from everyday life. Humans are social creatures that demand humans to live side by side, interact, communicate with one another. Cooperation is an action carried out with others to achieve common goals and mutual benefits. By working together, all group members can overcome small problems that both come within themselves and the group and can be responsible for tasks that must be completed so that the whole group member can achieve the goals together (Samani, 2012).

Character is defined as a character; character; psychological characteristics; morals or manners that differentiate a person from another. As a model of thoughts, feelings, attitudes, and actions that are strongly attached to a person. Thus, a person's character must be formed from childhood to be accustomed to positive behavior. Because failure to form character from childhood will cause behavior problems in adulthood. Therefore, the character-building of children must be done from an early age. Among the best means of strengthening children's character is through games that involve the child's physical and mental thinking. Traditional play can support children's thinking and physical involvement. Traditional children's games are a genre or form of folklore, which is a children's game. (Nadjamuddin, 2016).

Character development in students is very important to be a better individual and understand the values that apply. Character development is done by instilling basic ethical values such as one of which is cooperation. Observation results in the field, the problem found was that students preferred to be alone, and tended to work independently and indifferently when there were activities of cooperation in cleaning rubbish at school. Some students worked together to put rubbish in the garbage bag and the rest just sat and watched. Besides, students also play activities with friends, snacks, and play.

Playing is one of the activities that everyone likes. In elementary school children playing becomes a very fun activity, such as the results of a study which stated that the feeling of pleasure that arises is due to play (Sunarti, Istirahayu, \& Fitriyadi, 2017).

Aristotle said that there is a very close relationship between children's play activities and activities that children will do in the future. Furthermore, Herbart Spencer, argued that children play because children have excessive energy. This theory is often known as the Energy Surplus theory which says that playing (jumping, climbing, running, etc.) is a manifestation of the energy that exists within the child. 
Playing according to Spencer aims to replenish the energy of a child who has been weakened. (Christianti, 2007).

Playing is a fun activity that is carried out based on pleasure and without considering the result and is done voluntarily with the stages of development starting from the manipulative, symbolic, exploration, experimental and recognizable stages. Through playing aspects of motor, social, emotional development, children's language will develop if early childhood play activities are supported by three types of play, namely: sensorimotor play, role play, constructive play (Pratiwi, 2017).

Currently, the effect of this modernization era is a change in children's play activities from traditional games to modern/digital games that are identical to the use of technology such as on-line games, video games, and play stations. So that traditional games become foreign and begin to be neglected among children, so that it affects children's learning achievement, character crisis, and has aggressive behavior (Saputra, 2017).

One of the games is a traditional game. Lompat Tali is one of the many types of traditional games in Indonesia. The traditional jumping rope game is a jumping game with a rope obstacle in the form of a rope made of rubber that is knitted into a length (Febriani, 2015). Lompat Tali game or socalled independent rope jumping, or commonly known among the public that is a rubber game is a game that contains elements of competition, each group or team will compete, work together, form members to be active and can obey the rules of play to achieve group goals.

Traditional games have various benefits, especially for children. Research shows that children who play traditional games are far more developed abilities, including the ability to cooperate, sportsmanship, ability to build strategies, and dexterity (running, jumping, balance), and character (Yudiwinata, 2014).

The problem is the lack of cooperation in elementary students, it is necessary to have an effort to increase the value of student cooperation as character education. Based on several studies on the traditional game of Lompat Tali that can affect the value of cooperation, this study aims to apply the traditional Lompat Tali game to increase the value of student cooperation as an effort to preserve the nation's culture while increasing the value of character in the nation's generation.

\section{Methodology}

The study population was all elementary school students in Singkawang. Samples were selected using a purposive sampling technique as many as 50 groups.

The instrument for increasing cooperation attitude is in the form of an attitude scale. To support the results of the test analysis, the observation guidelines and interview guidelines are used. Observation guidelines are used when the traditional Lompat Tali game application takes place, then interview guidelines are used after the game is finished. In the process of analyzing research data, researchers make Table I, making it easier to recapitulate the stages of data collection.
TABLE I

DATA ANALYSIS

\begin{tabular}{lll}
\hline \multicolumn{1}{c}{ Activity } & \multicolumn{1}{c}{ Data } & $\begin{array}{c}\text { Data Analysis } \\
\text { Method }\end{array}$ \\
\hline $\begin{array}{l}\text { Analysis of } \\
\text { increasing } \\
\text { student }\end{array}$ & $\begin{array}{l}\text { The result of } \\
\text { the scale of } \\
\text { cooperation } \\
\text { attitude }\end{array}$ & $\begin{array}{l}\text { N-Gain test } \\
\text { attitude }\end{array}$ \\
\hline
\end{tabular}

\section{RESULTS AND DISCUSSION}

\section{A. Results}

The instrument for increasing cooperation attitude is in the form of an attitude scale. To support the results of the test analysis, the observation guidelines and interview guidelines are used. Observation guidelines are used when the traditional Lompat Tali game application takes place, then interview guidelines are used after the game is finished. Increasing students' cooperation attitude can be seen in Table II.

TABLE II

RESULTS OF INCREASING OF STUDENTS COOPERATION ATTITUDE THROUGH TRADITIONAL GAME OF LOMPAT TALI

\begin{tabular}{|c|c|c|c|c|}
\hline No & Group & Pre & Post & N-Gain \\
\hline 1 & $\mathrm{~A}$ & 21 & 31 & 0.67 \\
\hline 2 & B & 23 & 31 & 0.62 \\
\hline 3 & $\mathrm{C}$ & 22 & 32 & 0.71 \\
\hline 4 & D & 27 & 32 & 0.56 \\
\hline 5 & $\mathrm{E}$ & 25 & 32 & 0.64 \\
\hline 6 & $\mathrm{~F}$ & 21 & 27 & 0.4 \\
\hline 7 & $\mathrm{G}$ & 19 & 33 & 0.82 \\
\hline 8 & $\mathrm{H}$ & 23 & 32 & 0.69 \\
\hline 9 & I & 22 & 27 & 0.36 \\
\hline 10 & $\mathbf{J}$ & 21 & 29 & 0.53 \\
\hline 11 & $\mathrm{~K}$ & 22 & 33 & 0.79 \\
\hline 12 & $\mathrm{~L}$ & 22 & 24 & 0.14 \\
\hline 13 & M & 24 & 32 & 0.67 \\
\hline 14 & $\mathrm{~N}$ & 21 & 27 & 0.4 \\
\hline 15 & $\mathrm{O}$ & 27 & 30 & 0.33 \\
\hline 16 & $\mathrm{P}$ & 26 & 26 & 0 \\
\hline 17 & Q & 29 & 30 & 0.14 \\
\hline 18 & $\mathrm{R}$ & 22 & 24 & 0.14 \\
\hline 19 & S & 20 & 25 & 0.31 \\
\hline 20 & $\mathrm{~T}$ & 29 & 30 & 0.14 \\
\hline 21 & $\mathrm{U}$ & 22 & 26 & 0.29 \\
\hline 22 & V & 27 & 31 & 0.44 \\
\hline 23 & W & 23 & 32 & 0.69 \\
\hline 24 & $X$ & 23 & 29 & 0.46 \\
\hline 25 & $\mathrm{Y}$ & 23 & 29 & 0.46 \\
\hline 26 & Z & 21 & 29 & 0.53 \\
\hline 27 & AA & 22 & 31 & 0.64 \\
\hline 28 & $\mathrm{AB}$ & 23 & 27 & 0.31 \\
\hline 29 & $\mathrm{AC}$ & 29 & 30 & 0.14 \\
\hline 30 & $\mathrm{AD}$ & 24 & 28 & 0.33 \\
\hline 31 & $\mathrm{AF}$ & 22 & 27 & 0.36 \\
\hline 32 & $\mathrm{AG}$ & 24 & 27 & 0.25 \\
\hline 33 & $\mathrm{AH}$ & 24 & 28 & 0.33 \\
\hline 34 & AI & 25 & 29 & 0.36 \\
\hline 35 & AJ & 20 & 32 & 0.75 \\
\hline 36 & $\mathrm{AK}$ & 27 & 28 & 0.11 \\
\hline
\end{tabular}




\begin{tabular}{ccccc}
\hline No & Group & Pre & Post & N-Gain \\
\hline 37 & AL & 20 & 25 & 0.31 \\
38 & AM & 23 & 26 & 0.23 \\
39 & AN & 25 & 29 & 0.36 \\
40 & AO & 24 & 30 & 0.5 \\
41 & AP & 25 & 25 & 0 \\
42 & AQ & 23 & 26 & 0.23 \\
43 & AR & 27 & 34 & 0.78 \\
44 & AS & 25 & 27 & 0.18 \\
45 & AT & 26 & 28 & 0.2 \\
46 & AU & 24 & 28 & 0.33 \\
47 & AV & 23 & 25 & 0.15 \\
48 & AW & 24 & 27 & 0.25 \\
49 & AZ & 25 & 28 & 0.27 \\
50 & BB & 24 & 25 & 0.08 \\
\hline & & & SUM & 18.9 \\
& & & N-Gain & 0.38 \\
\hline
\end{tabular}

Based on Table II, traditional Lompat Tali can increase the cooperative attitude of elementary school students by 0.38. The data in Table II explains that students have a good cooperative attitude. This means that students have the same goals in achieving goals, visible attitude to help one another, the attitude of obeying the rules of the game, the existence of mutual communication between group members, have a sense of togetherness, mingle with one another regardless of differences, the division of tasks in groups.

\section{B. Discussion}

Traditional games can stimulate various aspects of child development which can include the following: (1) Motoric aspects by training endurance, flexural, sensorimotor, gross motor, and fine motor skills; (2) cognitive aspects by developing imagination, creativity, problem solving, strategies, anticipatory abilities, and contextual understanding; (3) emotional aspects by being a medium for emotional release, can hone empathy and self-control; (4) social aspects by conditioning children to be able to establish relationships, work together, train; (5) social maturity with peers and laying the foundation to practice socialization skills by practicing roles with older people and society in general (6) Spiritual aspects, traditional play can bring children to realize connection with something that is Godhead: (7) Ecological aspects by facilitating children to be able to understand the wise use of natural elements around; (8) Aspects of values or morals by facilitating children to be able to live the moral values inherited from the previous generation to the next generation (Nafisah, 2016).

Children who play traditional games have much more developed abilities and characters. The role of parents and teachers is also very important to preserve this traditional game which contains meaning and tradition. (Prisia, 2014). Besides, with traditional games children can train concentration, knowledge, attitudes, skills, and dexterity which are purely carried out by the human brain and body. Besides, traditional games can also develop aspects of moral development, religious, social, language, and motor functions (Andriani, 2012).
Efforts to form character can also be done through three stages, namely introducing the values of kindness through traditional games, encouraging children to realize good values when playing with traditional games, giving instructions for children to display good behaviors when playing with the traditional game (Witasari \& Wiyani, 2020).

The results of the study found that the implementation of educational traditional game models can effectively improve the character of early childhood. Through traditional educational games, it will help children develop various aspects of development in a holistic and integrated manner and develop positive characters (Hapidin \& Yenina, 2016).

The results of the study showed that there were thirteen (13) traditional game designs that are appropriate to the age of early childhood, and three (3) of the required guidance from adults/parents while in the process. The basic skills developed by traditional games are kinesthetic intelligence, linguistic intelligence, logical-mathematical intelligence, visual-spatial intelligence, musical intelligence, natural intelligence, interpersonal intelligence, intrapersonal intelligence, spiritual intelligence (Saputra \& Ekawati, 2017).

Traditional games function as (1) recreational functions; (2) Function as a learning medium, this is important especially for children. Physical competing games, for example, serve to develop the dexterity of the muscles of the players; (3) Competitive playing games have a function to develop thinking power; (4) The function of pedagogy which functions to educate a child, as well as an adult, is to be a person who has a sporting spirit and can work together (Nafisah, 2016). The traditional Lompat Tali game has several benefits that are good for gross motor, emotions, accuracy, and accuracy, socialization, intellectual, and morals that contain character values such as cooperation (Apriyani, Lusa, \& Purwadi, 2014).

The results of previous studies explain that the problems in education in Indonesia related to the formation of children's character and the urgency of the need to preserve traditional games as part of the nation's heritage become the background of research, and some main characteristics must be instilled in children, including respect and cooperation. These characteristics can be taught to children through traditional games because there are moral values in them (Nur, 2013).

Traditional games have a very important role in stimulating children's potential. In this case, the child is directly involved both physically and emotionally so that it greatly affects his growth period (Nurhayati, 2012).

\section{CONCLUSIONS}

The results of the study based on the $\mathrm{N}$-gain calculation show that the increase in the cooperative attitude of elementary school students is 0.38 , which means that students of the traditional game of Lompat Tali can increase the cooperative attitude of elementary school students. 


\section{REFERENCES}

Andriani, T. (2012). Permainan tradisional dalam membentuk karakter anak usia dini. Sosial Budaya, 9(1), 121-136.

Apriyani, N., Lusa, H., \& Purwadi, A. J. (2014). Meningkatkan Keterampilan Kinestetik Anak Melalui Permainan Tali Pada Kelompok B Paud Tunas Bangsa Kecamatan Ulu Manna Kabupaten Bengkulu Selatan. Skripsi. Universitas Bengkulu.

Christianti, M. (2007). Anak dan Bermain. Makalah. Kegiatan Jurnal Club Prodi PGTK Universitas Negeri Yogyakarta.

Febriani, E. (2015). Upaya Meningkatkan Pengembangan Motorik Kasar (Melompat) Anak Melalui Permainan Lompat Tali Pada Kelompok B TK AlHidayah Palaosan Tahun Pelajaran 2015-2016. Prosiding Ilmu Pendidikan, 1(2).

Hapidin, H., \& Yenina, Y. (2016). Pengembangan model permainan tradisional dalam membangun karakter anak usia dini. Jurnal Pendidikan Usia Dini, 10(2), 201-212.

Nafisah, W. (2016). Pengaruh permainan tradisional petak umpet dan lompat tali terhadap pembentukan karakter demokratis dan disiplin anak usia sekolah dasar di Sekolah Dasar Negeri Pakukerto 1 Sukorejo Kabupaten Pasuruan. Doctoral dissertation. Universitas Islam Negeri Maulana Malik Ibrahim.

Nadjamuddin, A. (2016). Membangun Karakter Anak Lewat Permainan Tradisional Daerah Gorontalo. Tadbir: Jurnal Manajemen Pendidikan Islam, 4(2), 74-79.

Nur, H. (2013). Membangun karakter anak melalui permainan anak tradisional. Jurnal Pendidikan Karakter, 1.

Nurhayati, I. (2012). Peran Permainan Tradisional Dalam Pembelajaran Anak Usia Dini (Studi di PAUD
Geger Sunten, Desa Suntenjaya). Empowerment: Jurnal Ilmiah Program Studi Pendidikan Luar Sekolah, 1(2), 39-48.

Pratiwi, W. (2017). Konsep bermain pada anak usia dini. TADBIR: Jurnal Manajemen Pendidikan Islam, 5(2), 106-117.

Prisia, Yudiwinata, H. (2014). Permainan tradisional dalam budaya dan perkembangan anak. Paradigma, 2(3).

Samani, M. (2012). Konsep dan Model Pendidikan Karakter. Bandung : PT Remaja RoSekolah Dasarakarya.

Saputra, S. Y. (2017). Permainan tradisional vs permainan modern dalam penanaman nilai karakter di sekolah dasar. ELSE (Elementary School Education Journal): Jurnal Pendidikan dan Pembelajaran Sekolah Dasar, 1(1).

Saputra, N. E., \& Ekawati, Y. N. (2017). Permainan tradisional sebagai upaya meningkatkan kemampuan dasar anak. Jurnal Psikologi Jambi, 2(2), 47-53.

Sunarti, J., Istirahayu, I., \& Fitriyadi, S. (2017). Emotional Analysis of Children in Class I Primary School. JBKI (Jurnal Bimbingan Konseling Indonesia), 2(1), 1-3.

Yudiwinata, Pambudi (2014). Permainan tradisional dalam budaya dan perkembangan anak. Jurnal Paradigma, 2(3).Ansor. (2009). Analisis Pengaruh ROA, PBV, EPS, PER, Kurs dan Suku Bunga terhadap Return Saham (Kajian Empiris pada Perusahaan Manufaktur yang Terdaftar di BEI Tahun 20062008). Tesis. Semarang: Program Pascasarjana Magister Manajemen, Universitas Diponegoro.

Witasari, O., \& Wiyani, N. A. (2020). Permainan Tradisional untuk Membentuk Karakter Anak Usia Dini. JECED: Journal of Early Childhood Education and Development, 2(1), 52-63. 